\title{
Assessment of Glucose, Total Protein, Albumin and Cholesterol Level and Its Correlation with Milk Production during Different Stages of Lactation in Indigenous and Crossbred Cows
}

\author{
M. Surya Prakash ${ }^{1}$, M.M. Pathan ${ }^{1 *}$,J.S. Arya ${ }^{2}$ and P.M. Lunagariya ${ }^{3}$ \\ ${ }^{1}$ Department of Veterinary Physiology and Biochemistry, College of Veterinary Science and \\ A. H., AAU, Anand, Gujarat, India \\ ${ }^{2}$ Aravalli college of Veterinary Science and Animal Husbandry, Rajasthan Agricultural \\ University, Sikar, Rajasthan, India \\ ${ }^{3}$ Livestock Research Station, College of Veterinary Science and Animal Husbandry, AAU, \\ Anand, Gujarat, India \\ *Corresponding author
}

\begin{tabular}{|c|c|}
\hline & A B S T R A C T \\
\hline Keywords & \multirow{4}{*}{$\begin{array}{l}\text { The study was undertaken to determine and compare the biochemical profile and its } \\
\text { correlation with milk production in cattle. The study was done on each of six Gir, Kankrej } \\
\text { and Crossbred cattle. The animals were divided in to three groups viz. 0-90 days of } \\
\text { lactation (Group I), } 91-180 \text { days of lactation (Group II) and } 181 \text { till dry stage (Group III). } \\
\text { Blood was collected aseptically before and after milking. The plasma biochemical } \\
\text { estimations were carried out on BS - } 120 \text { Chemistry Analyser (Mindray) using the } \\
\text { diagnostic kits. The values of glucose, more in Gir, as compared to Kankrej and } \\
\text { crossbreds, while cholesterol, total proteins and albumin, were higher in crossbreds as } \\
\text { compared to two other breeds. Stages of lactation had significant effect on all biochemical } \\
\text { parameters except albumin. Non-significant differences were observed between the } \\
\text { milking phases in all the stages and the breeds under study, however all the biochemical } \\
\text { parameters were higher in after milking phase. }\end{array}$} \\
\hline $\begin{array}{l}\text { Cattle, Biochemical } \\
\text { profile, Correlation, } \\
\text { Lactation, Milk } \\
\text { production }\end{array}$ & \\
\hline Article Info & \\
\hline $\begin{array}{l}\text { Accepted: } \\
\text { 10 March } 2018 \\
\text { Available Online: } \\
10 \text { April } 2018\end{array}$ & \\
\hline
\end{tabular}

\section{Introduction}

In the beginning of lactation, dairy cows have to cope with the high energy and protein demands for milk synthesis and also when nutrient intake is low. In an effort to obtain the energy necessary for milk production, the cows use up their bodily reserves, predominately fats. An energy deficit at the beginning of lactation negatively impacts, health efficiency and reproduction performance of dairy cows (Rao et al., 1981). Mobilizing energy and protein from body tissue stores and repartition of nutrients away from extra mammary tissues are the primary alternatives to supply sufficient nutrients for milk production during the first weeks of lactation (Suphake et al., 1989). Blood biochemical attributes are important indicators of the metabolic activity in lactating animals. During lactation, secretary cells of mammary gland utilize $80 \%$ of the blood circulating 
metabolites for milk synthesis, depending on the speed of infiltration of precursors of milk compounds (i.e. free amino acids, glucose and fatty acids).

The total protein, albumin, are necessary for the maternal requirements of proteins for milking and providing immunoglobulins. The most important indicators of energy status of ruminants are glucose, cholesterol and triglycerides. The blood glucose is utilized by the mammary gland for the synthesis of milk lactose. Total lipids, and cholesterol are significantly affected by the physiological status, probably because, around calving, there is an increase in the demands for regulatory mechanism, responsible for all the processes involved with preparation for milking. Lipolysis and lipogenesis are regulated to increase lipid reserve during pregnancy, and, subsequently, these reserves are utilized following parturition and the initiation of lactation. There is also paucity of literature regarding the detailed biochemical constituents analysis of Gir, and Kankrej cattle at different stages of lactation. Keeping in view the above points, the present study was undertaken in Gir, Kankrej and Crossbred cattle to determine the activity of the biochemical constituents, changes in the levels before and after milking, their correlation to milk production and to apply systematic health monitoring and the animal breeding status in order to identify changes that occur as a consequence of pathological processes and changes in the metabolic status in good time.

\section{Materials and Methods}

The research was approved by the Institutional Animal Ethics Committee (IAEC, No.: 179/VPY/2014). The study was carried out on six each of Indigenous Gir, Kankrej and Crossbred cattle maintained at the Livestock Research Station, Anand Agricultural University, Anand, Gujarat. Female cattle of various ages, party and Lactation stages were used, The animals were divided in to three groups viz. 0-90 days of lactation (Group I), 91-180 days of lactation (group II) and 181 till dry stage (group III). The average 300 days milk yield $(\mathrm{Kg})$ was $1839.20 \pm 86.66$ in Gir, $2213.73 \pm 134.62$ in Kankrej and $3393.22 \pm 383.10$ in Crossbred cows. The animals were maintained under standard feeding and management conditions followed at Livestock Research Station, Anand Agricultural University, Anand, Gujarat. In Gir and Kankrej, the practise of suckling and hand milking was followed and in crossbred it was weaning and machine milking.

Blood collection was conducted during the months of July 2014 to April 2015. Blood was collected aseptically, between $0600 \mathrm{hrs}$ to $0800 \mathrm{hrs}$ of the day, 20 minutes before milking (B.M) and within 5 minutes after completion of milking (A.F), through the jugular vein. Ten $\mathrm{ml}$ blood was collected in a single venepuncture in Lithium Heparin vacutainer. The plasma biochemical estimations were carried out in the Department of Physiology and Biochemistry, College of Veterinary Science and Animal Husbandry, Anand Agricultural University, Anand, on BS - 120 Chemistry Analyser (Mindray) using the diagnostic kits manufactured by Crest Biosystems, Coral Clinical Systems, Goa (India)

The data obtained in the present study were subjected to statistical analyses by using BASIC (Beginners All purpose Symbolic Instructional Code) programme of the computer and applying the Factorial Completely Randomised Design (CRD) as per Snedecor and Cohran (1990).

\section{Results and Discussion}

The plasma glucose increased significantly $(\mathrm{P} \leq 0.05)$ in both before and after milking 
stages with the advancement of lactation from stage -I to stage- III, in Gir, Kankrej and Crossbreds In each stage of the lactation a non-significant difference was observed between the milking phases (before and after milking) for plasma glucose. The range of mean plasma glucose in the present study was higher than that reported by Rao et al., (1981) and Sharma et al., (2001) for indigenous cattle, while it is in conformity with values reported by Ninan Jacob, (2012). The range of mean plasma glucose in our study was lower than that reported by Sreedhar et al., (2013) for indigenous cattle and Singh et al., (2005) for crossbred cattle. When the overall mean values, between the breeds and stages of lactation were compared it was observed that significantly $(\mathrm{P} \leq 0.05)$ higher values of plasma glucose were noted for crossbred cattle (86.58 $\pm 0.78)$ followed by Kankrej-(59.30 \pm 0.56$)$ and Gir cattle $(58.58 \pm 0.47)$, however this was not in agreement with the findings of Rawat et al., (2006), who reported higher values in indigenous cows. The plasma glucose differed significantly $(\mathrm{P} \leq 0.05)$ among the stages of lactation, in all the breeds. Glucose values increased along with the progress of lactation, with lowest values reported in stage-I $(65.31 \pm 0.77)$ followed by stage-II $(68.19 \pm 0.82)$ and highest value in stage-III (70.95 \pm 0.76$)$. The difference, may be due to the fact that in early lactation, milk yield is more and thus milk sugar lactose. Therefore, for more synthesis of lactose more glucose is required, and thus lower levels in circulation. These findings were similar as reported by Krsmanovic et al., (2013). However Suphke et al., (1989) reported highest glucose values at the beginning of lactation.

The relatively low levels of plasma glucose at lactation could be indicative of a greater demand for glucose by the mammary gland for the synthesis of lactose which in turn controls the milk volume. Maintenance of stable glucose concentration in blood involves, a finely regulated mechanism in which the liver, extra hepatic tissues and hormones like insulin, glucagon, epinephrine, glucocorticoids and thyroid hormones, play a major regulatory role (Collier, 1985).

The plasma total protein decreased significantly $(\mathrm{P} \leq 0.05)$ in both before and after milking stages with the advancement of lactation from stage -I to stage- III, in Gir while in Kankrej, the values increased in stage III of after milking stage. However, in the Cross bred the values increased significantly $(\mathrm{P} \leq 0.05)$ in both before and after milking stages from stage -I to stage- III, In each stage of the lactation a non-significant difference was observed between the milking phases (before and after milking) for plasma total protein. The range of mean plasma total protein in our study, was higher than that reported by Singh and Choudhary (1988) for indigenous cattle while Kumar et al., (2001) and Dhami et al., (2005) reported higher values for crossbred cattle. The finding in the present study on mean plasma total protein was in accordance with Singh et al., (1996) and Zambrano et al., (2009) for Crossbreed cattle and Ninan Jacob (2012), Mahima et al., (2013) for indigenous cattle. The range of mean plasma total protein in our study was lower than that reported by Amle et al., (2014) for crossbred cattle. When the overall mean values, between the breeds and stages of lactation were compared it was observed that, the plasma total protein differed significantly $(\mathrm{P} \leq 0.05)$ among the breeds with highest values being recorded for cross bred cattle with $(8.67 \pm 0.09)$ followed by Kankrej (6.76 $\pm 0.15)$ and Gir cows (6.69 \pm 0.12$)$ which are at par. The plasma total protein differed significantly $(\mathrm{P} \leq 0.05)$ among the stages with total plasma protein decreasing as the lactation progressed with highest values in stage I (7.61 $\pm 0.18)$ followed by stage-III $(7.27 \pm 0.14)$ which was at par with stage-II $(7.24 \pm 0.16)$. 
The findings were in conformity, with the studies of Ninan Jacob (2012) in Gir cattle in first stage of lactation and Rawat et al., (2006). The plasma total protein decreased with progress of lactation in Gir and Kankrej however it increased with advance of lactation in crossbred cattle. The physiological status or lactation stage of the cows significantly can change the serum levels of protein, (EI-Sherif and Assad, 2001). The higher concentrate to forage ratio provided during the early lactation is generally associated with lower levels of fibre and higher levels of starch in the diet, which gives rise to an increased production of propionic acid in the rumen and an increased microbial protein supply (Heck et al., 2009).This is reflected in the present study by an increase of total serum protein during the early stage of lactation.

The difference in the observations noted in the present study, with those of other authors may be due to the different breeds, stages of lactation, nutritional, management and environmental factors. Serum protein level indicates the balance between anabolism and catabolism of protein in the body and it's concentration at any given time in turn is a function of hormonal balance, nutritional status, water balance and other factors affecting health (Samanta and Das, 2007). Furthermore, this increase in protein concentrations may also be ascribed to a disproportionate increase of high protein fed to the yielders or an increased mobilization of protein in lactating animals (Setia et al., 1992).

The Plasma albumin decreased significantly $(\mathrm{P} \leq 0.05)$ in both before and after milking stages with the advancement of lactation from stage -I to stage- III, in Gir while in Kankrej, the decrease was not significant. However, in the cross bred the values increased significantly $(\mathrm{P} \leq 0.05)$ in both before and after milking stages from stage -I to stage- III, In each stage of the lactation a non-significant difference was observed between the milking phases (before and after milking) for plasma albumin. When the overall mean values, between the breeds and stages of lactation were compared, it was observed that the plasma albumin differed significantly $(\mathrm{P} \leq 0.05)$ among the breeds with highest values recorded in cross bred cattle $(4.68 \pm$ $0.08)$ followed by Kankrej $(4.03 \pm 0.09)$ and Gir cattle $(3.77 \pm 0.08)$. The plasma albumin did not differ significantly among the stages of lactation. However the decreasing rate of serum albumin in Gir and Kankrej could be due to the decreased rate of biosynthesis by the liver due to metabolic stress of lactation (Kulkarni and Talvelkar, 1984). Plasma albumin levels are a reflection of plasma protein levels. The physiological status or lactation stage of the cows significantly can change the serum levels of albumin, (Otto et al., 2000) (Table 1 and 2).

Table.1 Correlation between the biochemical constituents and milk yield in Gir, Kankrej and Crossbred cows

\begin{tabular}{|l|c|c|c|c|}
\hline & Glucose & Protein & Albumin & Cholesterol \\
\hline Gir & $-0.502 \pm 0.98$ & $-0.293 \pm 0.52$ & $-0.436 \pm 0.87$ & $-0.262 \pm 0.44$ \\
\hline Kankrej & $-0.487 \pm 0.89$ & $-0.308 \pm 0.98$ & $-0.426 \pm 0.62$ & $-0.242 \pm 0.33$ \\
\hline Cross bred & $-0.442 \pm 0.18$ & $-0.269 \pm 0.79$ & $-0.394 \pm 0.87$ & $-0.303 \pm 0.49$ \\
\hline
\end{tabular}


Table.2 Biochemical profile at different stages of lactation in indigenous and crossbred cattle (Mean \pm S.E.)

\begin{tabular}{|c|c|c|c|c|c|c|c|c|}
\hline \multirow[t]{3}{*}{ Parameter } & \multirow[t]{3}{*}{ Breed } & \multicolumn{6}{|c|}{ Stages of Lactation } & \multirow[t]{3}{*}{ Overall mean } \\
\hline & & \multicolumn{2}{|c|}{$\mathbf{I}$} & \multicolumn{2}{|c|}{ II } & \multicolumn{2}{|c|}{ III } & \\
\hline & & $\mathbf{B M}$ & $\mathbf{A F}$ & BM & $\mathbf{A F}$ & BM & $\mathbf{A F}$ & \\
\hline \multirow{4}{*}{$\begin{array}{l}\text { Glucose } \\
\text { (mg/dl) }\end{array}$} & Gir & $56.85^{b} \pm 0.32$ & $56.79^{f} \pm 0.28$ & $58.55^{\mathrm{a}} \pm 0.24$ & $58.55^{\mathrm{e}} \pm 0.21$ & $60.36^{\mathrm{a}} \pm 0.66$ & $60.38^{d} \pm 0.45$ & $58.58^{\mathrm{u}} \pm 0.47$ \\
\hline & Kankrej & $57.33^{\mathrm{i}} \pm 0.47$ & $57.46^{1} \pm 0.39$ & $59.38^{\mathrm{h}} \pm 0.47$ & $59.26^{\mathrm{k}} \pm 0.43$ & $61.33^{\mathrm{g}} \pm 0.33$ & $61.05^{\mathrm{j}} \pm 0.27$ & $59.30^{t} \pm 0.56$ \\
\hline & Cross bred & $81.80^{\circ} \pm 0.76$ & $81.65^{\mathrm{r}} \pm 0.75$ & $86.79^{\mathrm{n}} \pm 0.79$ & $86.62^{q} \pm 0.77$ & $91.51^{\mathrm{m}} \pm 0.72$ & $91.11^{\mathrm{p}} \pm 0.54$ & $86.58^{\mathrm{s}} \pm 0.78$ \\
\hline & Overall Mean & \multicolumn{2}{|c|}{$65.31^{x} \pm 0.77$} & \multicolumn{2}{|c|}{$68.19^{w} \pm 0.82$} & \multicolumn{2}{|c|}{$70.95^{v} \pm 0.76$} & \\
\hline \multirow{4}{*}{$\begin{array}{l}\text { Total } \\
\text { Protein } \\
\text { (g/dl) }\end{array}$} & Gir & $7.20^{\mathrm{a}} \pm 0.11$ & $7.11^{d} \pm 0.16$ & $6.63^{\mathrm{ab}} \pm 0.19$ & $6.53^{\mathrm{e}} \pm 0.18$ & $6.36^{b} \pm 0.12$ & $6.31^{\mathrm{e}} \pm 0.05$ & $6.69^{t} \pm 0.12$ \\
\hline & Kankrej & $7.40^{g} \pm 0.11$ & $7.21^{\mathrm{j}} \pm 0.03$ & $6.62^{h} \pm 0.18$ & $6.39^{\mathrm{k}} \pm 0.15$ & $6.45^{\mathrm{h}} \pm 0.13$ & $6.48^{\mathrm{k}} \pm 0.10$ & $6.76^{t} \pm 0.15$ \\
\hline & Cross bred & $8.35^{\mathrm{n}} \pm 0.06$ & $8.38^{\mathrm{q}} \pm 0.04$ & $8.67^{\mathrm{n}} \pm 0.06$ & $8.60^{\mathrm{q}} \pm 0.08$ & $9.04^{\mathrm{m}} \pm 0.11$ & $9.01^{\mathrm{p}} \pm 0.10$ & $8.67^{\mathrm{s}} \pm 0.09$ \\
\hline & Overall Mean & \multicolumn{2}{|c|}{$7.61^{v} \pm 0.18$} & \multicolumn{2}{|c|}{$7.24^{w} \pm 0.16$} & \multicolumn{2}{|c|}{$7.27^{w} \pm 0.14$} & \\
\hline \multirow{3}{*}{$\begin{array}{l}\text { Albumin } \\
\text { (g/dl) }\end{array}$} & Gir & $3.96^{\mathrm{a}} \pm 0.08$ & $3.97^{\mathrm{d}} \pm 0.06$ & $3.93^{\mathrm{a}} \pm 0.08$ & $3.77^{\mathrm{e}} \pm 0.04$ & $3.48^{b} \pm 0.07$ & $3.49^{\mathrm{e}} \pm 0.07$ & $3.77^{\mathrm{u}} \pm 0.08$ \\
\hline & Cross bred & $4.32^{\circ} \pm 0.06$ & $4.30^{\mathrm{r}} \pm 0.07$ & $4.70^{\mathrm{n}} \pm 0.06$ & $4.61^{\mathrm{q}} \pm 0.07$ & $5.11^{\mathrm{m}} \pm 0.03$ & $5.06^{p} \pm 0.03$ & $4.68^{\mathrm{s}} \pm 0.08$ \\
\hline & Overall Mean & \multicolumn{2}{|c|}{$4.16 \pm 0.08$} & \multicolumn{2}{|c|}{$4.15 \pm 0.10$} & \multicolumn{2}{|c|}{$4.16 \pm 0.11$} & \\
\hline \multirow{4}{*}{$\begin{array}{c}\text { Cholesterol } \\
\text { (mg/dl) }\end{array}$} & Gir & $173.20^{c} \pm 0.74$ & $172.71^{\mathrm{f}} \pm 0.06$ & $180.40^{\mathrm{b}} \pm 0.85$ & $179.25^{\mathrm{e}} \pm 1.22$ & $191.03^{\mathrm{a}} \pm 1.13$ & $195.40^{\mathrm{d}} \pm 1.74$ & $181.99^{t} \pm 2.11$ \\
\hline & Kankrej & $174.05^{\mathrm{h}} \pm 1.32$ & $173.76^{\mathrm{k}} \pm 1.13$ & $179.88^{\mathrm{h}} \pm 0.79$ & $179.54^{k} \pm 0.93$ & $195.97^{\mathrm{g}} \pm 2.34$ & $195.96^{\mathrm{j}} \pm 2.05$ & $183.19^{t} \pm 2.38$ \\
\hline & Cross bred & $180.81^{\mathrm{n}} \pm 2.85$ & $180.53^{q} \pm 2.78$ & $186.99^{\mathrm{n}} \pm 1.65$ & $186.05^{\mathrm{p}} \pm 1.59$ & $190.20^{\mathrm{m}} \pm 1.02$ & $189.14^{\mathrm{p}} \pm 1.19$ & $185.62^{\mathrm{s}} \pm 1.99$ \\
\hline & Overall mean & \multicolumn{2}{|c|}{$175.84^{\mathrm{x}} \pm 2.22$} & \multicolumn{2}{|c|}{$182.02^{\mathrm{w}} \pm 1.85$} & \multicolumn{2}{|c|}{$192.95^{\mathrm{v}} \pm 1.89$} & \\
\hline \multicolumn{9}{|c|}{ 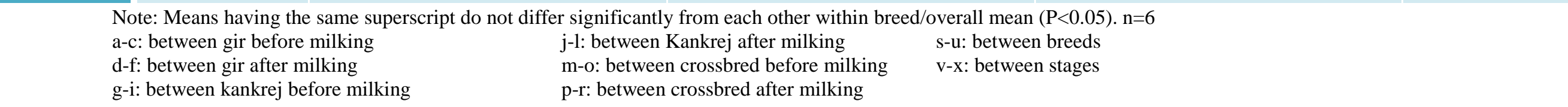 } \\
\hline
\end{tabular}


The increase in values observed in crossbred cattle might be due to the fact that albumin is a transport protein and remains involved in transport of calcium, phosphorus, free fatty acids, fat soluble vitamins etc. So, with progression in lactation, the animal body has some mechanism which triggers to high albumin synthesis to accommodate the transport of several nutrients to the mammary gland (Rana et al., 2009).

The plasma total cholesterol increased significantly $(\mathrm{P} \leq 0.05)$ in both before and after milking stages with the advancement of lactation from stage -I to stage- III, in Gir, Kankrej and Crossbreds. In each stage of the lactation a non-significant difference was observed between the milking phases (before and after milking) for plasma glucose. The Mean \pm S.E levels of plasma total cholesterol reported in the present study was higher than the value reported by Mahima et al., (2013) in indigenous cattle and Singh et al., (1996) in cross bred cattle. However the values were similar to findings of Ninan Jacob, (2012) and Rawat et al., (2006) in indigenous cattle and Yaylak et al., (2009) in crossbred cattle. Jadhav et al., (1977) reported lower values than observed in present study in Indigenous cattle. When the overall mean values, between the breeds and stages of lactation were compared it was observed that significant $(\mathrm{P} \leq 0.05)$ breed differences were observed in the present study with maximum values recorded for cross bred cattle (185.62 \pm 1.99) followed by Kankrej (183.19 \pm 2.38) and Gir cows $(181.99 \pm 2.11)$ which are at par. The effect of stages of lactation was significant $(\mathrm{P} \leq 0.05)$ with total cholesterol values increasing as the lactation progressed from stage-I (175.84 \pm 2.22$)$ to stage-III $(192.95 \pm$ 1.89). Similar finding were observed by Rawat et al., (2006), in Indigenous cattle. While, Picconne et al., (2012) and Krsmanovic et al., (2013) reported the similar finding as observed in the present study in cross bred cattle. The plasma cholesterol values increased significantly as the lactation progressed in all the breeds under the study.

Cholesterol is needed for steroidogenesis. The slightly higher values in pregnant and early lactation are suggestive of increased steroidogenesis (Pal et al., 1991). Moreover, oestrogens influence lipid metabolism through lipogenesis, which causes increased turnover of cholesterol. Additionally cholesterol acts as a fatty acid carrier in the form of cholesterol esters for milk synthesis. This may explain the increased concentration of cholesterol observed in the present study during lactation in all the breeds as higher concentration of cholesterol during lactation is a physiological adjustment to meet lactation requirements (Rawat et al., 2006). Patel et al., (2010) reported that the plasma total cholesterol, the precursor of steroid hormones, is closely associated with physiological status of animal, reproduction and lactation. They suggested that increasing trends of cholesterol concentration postpartum help in gonadal steroidogenesis, which subsequently increase the ovarian rebound and in pregnancy. Krsmanovic et al., (20013) reported that total cholesterol and triglycerides levels were significantly affected by the physiological status. Probably because during the puerperal period, there is an increase in the demands for regulatory mechanism, responsible for all the processes involved with milking. The physiological status or lactation stage of the cows significantly can change the serum levels of cholesterol (Peterson and Walden, 1981). Serum cholesterol levels may be affected by fat content in high ratios during gestation stress and in the early stages of lactation; they may cause an increase in serum cholesterol (Ruegg et al., 1992). Decrease in thyroid activity may explain the rise in serum cholesterol during mid-lactation, as in this 
stage, cows are generally in a positive energy balance. Tissues such as the corpus leuteum and adrenal glands, use cholesterol for hormone synthesis, and thus, cholesterol levels may change in lactation period (Arave et al., 1975).

Significant breed differences were observed in all the biochemical parameters under study, with the values of glucose, more in Gir, as compared to Kankrej and crossbreds, while cholesterol, total proteins and albumin, were higher in crossbreds as compared to two other breeds. Stages of lactation had significant effect on all biochemical parameters except albumin. The overall mean levels of glucose and cholesterol increased with progress of lactation, while the overall mean levels of total proteins decreased as the lactation advanced. Non-significant differences were observed between the milking phases in all the stages and the breeds under study, however all the biochemical parameters were higher in after milking phase.

\section{References}

Arave, C. W., R.H. Miller and R.C. Lamb, (1975).Genetic and environmental effects on serum cholesterol of dairy cattle of various ages. J. Dairy Sci., 58:423-427.

Collier, R. J. (1985). Nutritional, metabolic and environmental aspects of lactation. In Lactation. ${ }^{\text {st }}$ edn. Ed. Larson, B.L., Iowa state university press, U.S.A. P.102-110.

Dhami, A.J., Lakum, P.D., Patel, P.M., Panchal, M.T. and Kavani, F.S. (2005). Blood biochemical profile in relation to age and reproductive status of Holstein Friesian cattle reared under tropical climate. Indian J. Anim. Reprod., 26(1): 34-38.

El-Sherif, M.M. and F, Assad, (2001). Changes in some blood constituents of
Barki ewes during pregnancy and lactation under semi-arid conditions. Small Rumin. Res., 40:269-277.

Heck, J.M.L., van Valenberg, H.J.F, Djikstra, J., van Hooijodonk, A.C.M. (2009). Seasonal variation in the Dutch bovine raw milk composition. Journal of dairy Science, 92. P. 4745-4755.

Jadhav, S.S., Velhankar, D.P. and Deshpande, B.R. (1977). Variation in the serum cholesterol levels of Gir cows during pregnancy, parturition and puerperum. Indian Vet. J., 54(7): 536-540.

Krsmanovic, M., Djokovic., R. and Bojkovski, J. (2013). Determination of characteristics of blood in peripartal and peak lactation dairy cows. Bulletin of University of Agricultural Science and Veterinary Medicine. 70 (2):258-265.

Kulkarni, B.A. and Talvelkar, B.A. (1984).Studies on serum biochemical constituents in lactating and dry buffaloes. Indian vet. J. 61(7):564-568).

Kumar, R., Sharma, I.J., Rao, M.L.V. and Quadri, M.A. (2001).Status of haemogram, plasma proteins, minerals and electrolytes during pregnancy anorexia and sub-clinical ketosis in cows and buffaloes. Indian J. Anim. Sci's., 71(2):118-121.

Mahima, K. V., Verma, A. K., Vinod Kumar, Singh, S. K. and Debashis Roy (2013) Haematological and serum biochemical profile of apparently healthy Hariana cattle heifers in northern India. Paki. Journal of Bio. Science.16 (21):14231425.

Ninan Jacob. (2012). Haematological, biochemical and endocrine parameters at different ages and Physiological stages in Gir Cattle and Jaffrabadi Buffaloes. Ph.D. Thesis, Anand agricultural university, Anand.

Otto, F., Vikela, F.M., Harum, G., Taylor, P., Bagasse and Bogei, E. (2000). Biochemical blood profile of Angoni 
Cattle in Mozambiae. Israel Journal of Veterinary Medicine. 55(3):336- 342

Pal, S. K., Mohanty, B.N., Ray, S. K. H and Mohanty, D.N. (1991). Studies on serum protein, cholesterol and certain enzymes in relation to reproductive status in bovine females. Indian.J.Anim.Reprod., 12(1): 28-29.

Patel, B. B., Patel, D. M., Patel, J. A. and Belsare, V. P.(2010). Effect of hormonal and herbal therapies on total cholesterol and triglycerides profile in Holstein Friesian cows. Indian J. Anim. Reprod., 31(1):44-47

Peterson, R. G. and Waldern, D. E. (1981). Repeatabilities of serum constituents in Holstein-Friesians affected by feeding, age, lactation and pregnancy. J. Dairy Sci., 64:822-831.

Picconne, G., Mesina. V., Marafioti, S., Casella, S., Giannetto, C., and Fazio, F. (2012). Changes of some haematochemical parameters in dairy cows during late gestation, post-partum, lactation and dry periods. Vet.Med.Zoot. 58:59-64.

Rana, T., Sarkar, S., Mandal, T. and Batabyal, S. (2008). Haemato-biochemical profiles of affected cattle at arsenic prone zone in Haringhata block of Nadia district of west Bengal in India. The Internet J. Hemotology, 4(2):9-15.

Rao, G.D., Amba Prasad, A.B., Jayarama Krishna, V. and Satyanarayana Rao, K. (1981). Studies on some biochemical constituents of blood in Ongole cows. Indian Vet. J., 58(11): 870-873.

Rawat, B., Nigam, R. and Jain, A.K. (2006). Metabolic profile in late pregnancy and early lactation in Haryana and crossbred cows. Indian Vet. J., 83(7): 795-797.

Ruegg, P. L., W. J. Goodger, C. A. Holmberg, L. D. Weaver and E. M. Huffman, (1992). Relation among body condition score, milk production and serum urea nitrogen and cholesterol concentrations in high-producing Holstein dairy cows in early lactation. Am. J. Vet. Res.53:59.

Samanta, A.K. and Dass, R.S. (2007). Effect of Vitamin E supplementation on growth, nutrient utilization, blood biochemical and enzymatic profile in male crossbred (Bos indicus $\mathrm{x}$ Bos taurus) calves. Int. J. Cow Sci., 3(1\&2): 34-43.

Setia, M.S., Duggal, R.S. and Singh, R. (1992). Biochemical constituent of blood in buffaloes and cows during late pregnancy and different stages of lactation - a longitudinal study. Buffalo J., 2: 123-129.

Sharma, I.J., Quadri, M.A., and Rakeshkumar (2001). Blood glucose, ketone bodies and gluconeogenic enzyme activities in the lactating cows and buffaloes. Cheiron, 30 (5\&6): 172-173.

Singh, A. and Chaudhary, R.P. (1988). Biochemical studies in Sahiwal and crossbred cattle. Indian Vet. J., 65(9):791-796.

Singh, M., Anjali Aggarwal and Dang, A.K. (2005). Mister cooling effects on haematology of crossbred cows during extreme summer conditions. Ind. $J$. Dairy. Sci. 58(6): 410-414.

Singh, S.K., Singh, V.P. and Singh, H.S. (1996). Studies on physiological and biochemical attributes of three breed crossbred cows during estrus. Indian J. Anim. Prod. Mgmt. 12(1):17-19.

Snedecor, G.W. and Cochran, W.G. (1990). Statistical Methods, $8^{\text {th }}$ ed. Iowa State University Press, Iowa, USA.

Sreedhar Suratani, Kapa, S. Rao, Jeepalyam Suresh, P.R.S. Moorthy and Reddy V. P. (2013). Changes in haematocrit and some serum biochemical profile of Sahiwal and Jersey X Sahiwal cows in tropical environments. Veterinar Ski. Archiv. 83(2):171-187. 
Suphke, E., Junge, W., Preisinger, R., and Katam, E. (1989). Substrates, enzymes and hormones in high yielding cowsrelations between metabolic values and feed intake criteria. Journal of Animal Breeding Abstracts. 106(5):363-372

Yaylak, E., Yenisey, C. and Seyrek, K. (2009). Effect of lameness stages of lactation and body condition score on some blood parameter in Holstein cows. Asian Journal of Animal and Veterinary Advances; 4(5): 245-251.

Zambrano, N. J and Marous, A. D., Jr. (2009). Metabolic profile of cross bred milking cows from calving to fifth month of lactation. Zootecnia tropical, 27(4): $475-488$.

\section{How to cite this article:}

Surya Prakash, M., M.M. Pathan, J.S. Arya and Lunagariya, P.M. 2018. Assessment of Glucose, Total Protein, Albumin and Cholesterol Level and Its Correlation with Milk Production during Different Stages of Lactation in Indigenous and Crossbred Cows. Int.J.Curr.Microbiol.App.Sci. 7(04): 1248-1256. doi: https://doi.org/10.20546/ijcmas.2018.704.139 